\title{
The benefits of geographical indication certification through farmer organizations on low-income farmers: the case of Hoa Vang sticky rice in Vietnam
}

\author{
Huaiyu Wang ${ }^{1}$, Dao The $\mathrm{Anh}^{2}$ and Paule Moustier ${ }^{3,4, *}$ \\ ${ }^{1}$ School of Management and Economics, Beijing Institute of Technology, 5 South Zhongguancun Street, Haidian District, Beijing \\ 100081, China \\ ${ }^{2}$ Vietnam Academy of Agricultural Sciences, Hanoi, Vietnam \\ 3 CIRAD, UMR MoISA, 34398 Montpellier, France \\ ${ }^{4}$ MoISA, Univ Montpellier, CIHEAM-IAMM, CIRAD, INRAE, Institut Agro, IRD, Montpellier, France
}

\begin{abstract}
Origin labeling and quality upgrading through farmer organizations have been considered as solutions to reduce transaction costs and improve market bargaining power. This paper explores whether belonging to a farmer organization that improves and signals quality can help increase yields and household incomes of small-scale farmers for a specific quality product, Hoa Vang sticky rice in Vietnam. The paper is based on primary data on 185 households collected in 2013 and on 149 households collected in 2015 . Different econometric methods were applied to investigate the effect based on rice yield, rice income and household income as the outcome variables. The results show that membership of farmer organization does not significantly improve household income compared to non-membership. However, members of farmer organizations have less resources in terms of land and inputs than non-members. These results suggest that the economic results achieved by farmers with fewer opportunities to access markets are similar to those obtained by farmers with more opportunities thanks to the involvement of farmer organizations in marketing. The specificities of the Hoa Vang sticky rice are still not reflected in higher farmer sales prices and incomes. More dialogue between farmer organizations and their customers is thus required, as well as better public control of labeling fraud.
\end{abstract}

Keywords: geographical indication / farmer organization / sticky rice / Vietnam / income

Résumé - Les avantages de la certification de l'indication géographique par les organisations de producteurs pour les agriculteurs à faible revenu: le cas du riz gluant Hoa Vang au Vietnam. L'indication géographique et l'amélioration de la qualité par le biais des organisations de producteurs sont considérées comme des solutions pour réduire les coûts de transaction et améliorer les capacités de négociation sur les marchés. Cet article examine si l'appartenance à une organisation de producteurs qui améliore et signale la qualité peut contribuer à augmenter les rendements et les revenus des ménages de petits agriculteurs pour un produit de qualité spécifique, le riz gluant Hoa Vang au Vietnam. L'article est basé sur des données primaires collectées auprès de 185 ménages en 2013 et 149 ménages en 2015. Différentes méthodes économétriques ont été appliquées pour étudier l'effet de l'appartenance à une organisation en prenant comme variables de résultat le rendement du riz, le revenu du riz et le revenu du ménage. Les résultats montrent que l'adhésion à une organisation de producteurs n'améliore pas significativement le revenu des ménages par rapport à la nonadhésion. Cependant, les membres des organisations de producteurs disposent de moins de ressources en termes de terres et d'intrants que les non-membres. Ces résultats suggèrent que les résultats économiques obtenus par les agriculteurs ayant moins de possibilités d'accéder aux marchés sont similaires à ceux obtenus par les agriculteurs ayant davantage de possibilités, grâce à l'implication des organisations de producteurs dans la commercialisation. Les spécificités du riz gluant Hoa Vang ne se traduisent toujours pas par des prix de vente et des revenus plus élevés pour les agriculteurs. Un dialogue accru entre les organisations de producteurs et leurs clients est donc nécessaire, ainsi qu'un meilleur contrôle public de la fraude à l'étiquetage.

Mots clés : indication géographique / organisation de producteurs / riz gluant / Vietnam / revenu du ménage

*Corresponding author: paule.moustier@cirad.fr 


\section{Introduction}

Improving smallholders' access to markets is crucial to guarantee better livelihoods in emerging economies. When small farmers are located in areas with specific advantages for certain agricultural commodities, origin and quality labeling is considered by many scholars as an excellent strategy to improve market access, thanks to price premiums and/or a higher share in the distribution of added value (Neilson et al., 2018). Yet scholars generally fail to provide rigorous evidence for the positive impact of such schemes on farmers' incomes. There are indeed many difficulties in empirically evaluating the impact of a geographical indication (GI) in countries where protected designation of origin (PGI) has only recently been introduced (Bramley et al., 2009).

The objective of this paper is to assess the impact of origin certifying by farmer organizations on small farmers' incomes in northern Vietnam. Origin certification here refers to farmers who respect specifications concerning product origin and quality and sell their product under a label referring to a geographical indication. We chose the case of Hoa Vang sticky rice in Hai Duong Province for the following reasons. First, Hoa Vang sticky rice is a staple food crop in Vietnam whereas most of the literature on GIs concerns export crops. Second, Hoa Vang sticky rice already has a good reputation among Vietnamese consumers. Third, it is strongly supported by the regional authorities in charge of agriculture.

\section{Literature review}

A geographical indication is defined by the World Trade Organization as the identification "of a good originating in a place, where a given quality, reputation, or other characteristic of the good is essentially attributable to its geographical origin" (Biénabe and Marie-Vivien, 2017:58).

As pointed out by Neilson et al. (2018), many authors claim that geographical indications have very positive influence on rural development because they are used to signal to consumers unique and valued characteristics in terms of quality, culture or rural development (Belletti and Marescotti, 2011; Belletti et al., 2017; Bramley et al., 2009; Giovannucci et al., 2009). A reputation for good quality is a coping mechanism that avoids the negative consequences of asymmetries of information between producers and consumers regarding quality. The protection offered by geographical indications is an example of the market placing value on more than just economic factors, which should lead to premium prices for farmers (Williams, 2007; Bramley et al., 2009).

However, some studies have shown that origin labeling has a limited impact on farmers' incomes for several reasons. The price premium for the geographical indication may be captured by traders rather than producers (Hughes, 2009; Galtier et al., 2013). The impact may be constrained by lack of compliance with quality specifications and the absence of sanctions for fraud (Neilson et al., 2018). The benefits of origin labeling may also be limited by consumers' unwillingness to pay for what may be a small increase in quality (Desquilbet and Monier-Dilhan, 2015). In the case of coffee in Indonesia,
Neilson et al. (2018) pointed to a misalignment between the geographical indication (GI) strategy and the priorities of downstream users who are mostly concerned by quality assurance in terms of material quality, including appearance and taste, rather than symbolic quality (including origin and cultural aspects). Until a stable market for GIs has been established with guaranteed economic benefits, farmers may thus be reluctant to join such schemes (Ilbery et al., 2005).

However, origin labeling may be valuable for smallholder farmers as, unlike large scale famers, they lack the necessary resources to invest in advertising, especially if they share the labeling costs through farmer organizations (Bontemps et al., 2013). Farmer organizations play an important role in the promotion of specific quality attributes, particularly when they are linked to conditions that are specific to a region (Cook and Chambers, 2007; Fałkowski and Ciaian, 2016; Michalek et al., 2018). Farmers' collective action helps reduce transaction costs, improve quality standards and increase bargaining power by linking smallholder farmers to the market (Moustier et al., 2010; Abebaw and Haile, 2013; Deng et al., 2010; Ma and Abdulai, 2017).

Public support for geographical indications usually includes the provision of extension services. In Vietnam and Indonesia, the development of geographical indications is combined with the public objective of modernizing agriculture through good agricultural practices promoted in the codes of practices (Durand and Fournier, 2017). These new practices may increase yields but may also increase production costs, which have to be counterbalanced by significant premium prices. Some authors suggest that cooperatives are more efficient in providing inputs, services and technical knowledge thereby increasing yields than in obtaining higher sales prices (Chagwiza et al., 2016; Ofori et al., 2019). Impact evaluation of basmati rice in India revealed increased production costs but also higher sales prices and hence higher incomes (Jena and Grote, 2012). However, such rigorous evaluations are still rare. As argued by Tregear et al. (2016, p. 435), there is also a need to assess the heterogeneity of GI systems, especially mature versus emerging systems in which producers' connections with each other are more recent or tenuous, and the reputation of the protected product is weaker or more limited, consequently resulting in less certain premiums. The ability of farmers' groups to master marketing skills and partner with other operators in the chain is reported to be strategic for such premiums (Tregear et al., 2016; Neilson et al., 2018).

In short, the literature suggests that origin and quality certification through farmer organizations can have a positive impact on farmers' prices if farmer organizations have a successful marketing strategy in terms of partnerships with distribution agents and advertising, which may be especially valuable for smallholder farmers. The effects on yields remain unclear. Geographical indications acquired through farmer organizations have positive impacts on farmers' yields if they facilitate access to training and agricultural inputs, but there may be a trade-off between quality and yield. Origin and quality certification through farmer organizations may thus have no direct positive effects on farmers' incomes. We test these hypotheses using the case of Hoa Vang sticky rice in Vietnam. 


\section{The development of Hoa Vang sticky rice in Vietnam}

Hoa Vang sticky rice (hereafter "HV sticky rice", "Hoa Vang' means golden flower) is a special rice grown in Hai Duong Province in Vietnam. It has been grown there for decades and is mainly consumed during festivals celebrated by the Vietnamese people. In Kinh Mon District, Hai Duong Province, HV sticky rice has a good reputation among consumers. When cooked, the grains are white, of uniform size, intact (not broken), soft and gluey, not gooey, with a distinctive fragrance and with a high proportion of protein and certain amino acids.

These characteristics are hypothesized to be related to the special attributes of the climate and hydrology of the region, as well as to the attributes of the traditional variety, and farmers' cultivation know-how. HV sticky rice is famous both in and beyond the province as a specialty of Kinh Mon District. Yet a number of traders use its good reputation to market rice from other regions under the name "Hoa Vang", despite lower quality, which reduces prices, with bad quality driving out good (Akerlov, 1970).

Kinh Mon District covers 16,326 ha, including 9,518 ha of agricultural land of which 7,300 ha is used for annual crops, the rest for perennial crops and aquaculture. In parallel with paddy and corn, vegetable cultivation is expanding, e.g., onions and garlic, which have a higher economic return than rice. The total cultivated acreage of sticky rice in Kinh Mon District is around 500 ha with a yield of 3.5 tons/ha. HV sticky rice has a long growing season of around 150 days. The plant can withstand harsh natural conditions, with relatively good resistance to alkaline or acidic soilsand drought.

To boost production, and to extend the acreage under HV sticky rice in the district, the Kinh Mon District People's Committee provides a seed subsidy that covers $50 \%$ of the cost of seed. The Hai Duong Department of Science and Technology set up a project named "Building, managing and developing the Gao HV sticky rice collective brand for HV sticky rice products of Kinh Mon District, Hai Duong Province." The collective brand is registered by the National Organization of Intellectual Property. Kinh Mon District planned to create a HV sticky rice production zone in nine communes with a goal of 500 ha between 2011 to 2015. This policy was implemented in five villages: Hiep An, Hien Thanh, Hiep Son, Hoanh Son, Duy Tan with 1,208 participating households and a total of 113.5 ha rice area.

The HV Sticky Rice Production and Commerce Association of Hai Duong was created in 2006 with 36 members for a production acreage of 2.3 ha in An Phu commune. In 2008, it was composed of three farmer groups with 131 members located in three communes (An Phu, Long Xuyen and Pham Menh), representing 10 hectares of sticky rice. In 2012, it was expanded to two other communes (Hien Thanh and Duy Tan), the number of members reached 367 and the cultivated area 25 hectares. The association has clear rules and operating plans certified by the People's Committee, in particular production specifications concerning the site of production, the type of seeds used (the restored, traditional variety), the (limited) use of chemical inputs offset by organic fertilizers, and thorough cleaning of the grain, including mechanized dust removal.
Farmers' groups were formed with the objective of expanding the acreage of HV sticky rice with traditional good quality rice thereby increasing their members' income. The objective is also to guarantee the origin of traditional, high-quality products for consumers thanks to a well-designed marketing strategy including packaging, labeling and advertising. However, no quantitative studies have been conducted to date to evaluate if these strategies for developing and signaling quality result in higher economic results for HV sticky rice farmers. This is the objective of the present paper.

\section{Data and methods}

\subsection{Data}

We conducted two rounds of surveys on sticky rice production in Kinh Mon District, the first in 2013 and the second in 2015. 2013 turned out to be an abnormal year for sticky rice production due to flooding. This affected the quality of the grain rather than the yield and consequently the market price, leading us to hold another survey in 2015. As income is always a sensitive topic, we chose to keep the questionnaire short and to spend sufficient time with the farmer to build up trust in order to obtain details on their farming operations. The first survey focused on the farmers' characteristics, agricultural practices and input-output data concerning sticky rice. In the second survey, as the farmers already knew the members of our team, we were able to ask for additional information, including data on household income in addition to information about their crops. To estimate the income from rice, we deducted the farmer's production costs from the farmer's revenue. To estimate revenues, we asked the farmer about the harvesting calendar, the yields, and the sales price at each harvest. To estimate costs, we asked about the quantities and prices of all agricultural inputs and other costs, including depreciation of equipment and the cost of labor.

The communes where the HV sticky rice Production and Commerce association was first established were selected for the survey. Farmers were interviewed randomly when the interviewers went to the field. Interviewers started with the first farmer they met upon entering the village. If the farmer was not available for interview, they moved on to the next one and so on.

A total of 185 farmers were interviewed in 2013, and 149 farmers in 2015. In 2015, we did our best to interview as many farmers interviewed in 2013 as possible but this proved to be difficult because the same farmers were not always available. In the end, we were only able to interview 51 farmers twice.

We included members and non-members of the association in the different communes, i.e., An Phu (An Land and Co Tan villages), Duy Tan (Duyen Linh village), Pham Menh (Linh Dong village), An Sinh (Nghia Vu and Van O), and Long Xuyen (Ngu Uyen). Table 1 shows the distribution of members and non-members of the association. Our sample represented more than $15 \%$ of the population of sticky rice farmers, which was estimated at 1,208 households in 2013. It can be considered as a representative sample with a less than $15 \%$ error considering the variance in rice income of 11.23 with a means of $50.18 \mathrm{MVND} / \mathrm{ha}(1 \mathrm{VND}=\mathrm{US} \$ 0.00005$ in 2013 2015). 
Table 1. Sample distribution in the survey.

Tableau 1. Distribution de l'échantillon dans l'enquête.

\begin{tabular}{lrr}
\hline & 2013 & 2015 \\
\hline Members & 80 & 82 \\
Non-members & 105 & 67 \\
Total & 185 & 149 \\
\hline
\end{tabular}

We also conducted interviews with traders who collect sticky rice in Kinh Mon District, plus collectors, wholesalers and retailers in Hanoi, Hai Duong, and Ho Chi Minh cities to obtain their opinion on labeled and unlabeled sticky rice. A workshop was organized in 2016 with leaders of farmers' groups and local officials to present and discuss the results of the surveys.

\subsection{Methods}

Descriptive analysis was used to compare basic household characteristics. The impact evaluation approach has evolved considerably and different econometric methods have been developed over the past two decades (Khandker et al., 2010). The choice of a particular method in a specific context is always recommended for empirical economic analysis in different fields with multiple available options to design and assess a program; moreover, a good control group is indispensable for successful impact evaluation (Khandker et al., 2010).

The hypothesis we aimed to test is whether origin certification through farmer organizations significantly influences farmers' performance and household income, and if the effects differ depending on each farmer's economic profile. Therefore, quantile estimation according to Koenker and Bassett (1978) is needed to investigate the effect of origin labeling on different rice farmers associated with their income. In our model, we used the following quantile equation for the estimation:

$$
\operatorname{Quant}_{\theta}\left(\text { hhinc }_{i} \mid M_{i}\right)=\lambda_{\theta} M_{i}
$$

where $\theta$ is the quantile of the estimation, and $M_{i}$ is the explanatory variables. Quant (hhinc $_{i} \mid M_{i}$ ) denotes the different quantiles $(0<\theta<1)$ conditional on $M_{i} . \lambda_{\theta}$ is the coefficient of quantile $\theta$ that minimizes the residuals.

To estimate the impact of origin labeling, we used propensity score matching (PSM) techniques reported in the literature on average treatment effects to correct the selection bias resulting from the farmer's decision and output (Jalan and Ravallion, 2003; Maertens and Swinnen, 2009; Imbens 2004; Abebaw et al., 2010). Score matching techniques reduce the dimension for matching between participants and nonparticipants whose observable characteristics are similar (Dehejia and Wahba, 2002; Caliendo and Kopeinig, 2008). This is a popular approach used to estimate the effects of treatment in different research domains to correct potential self-selection biases (see Caliendo and Kopeinig (2008) for review). The average treatment effects on the treated group can thus be estimated as follows:

$$
\begin{aligned}
& \mathrm{ATT}=\mathrm{E}\left(\mathrm{E}\left(Y_{i, \text { member }} \mid T_{i}=1, p(X)\right)\right. \\
& \left.\quad-\mathrm{E}\left(Y_{i, \text { non-member }} \mid T_{i}=0, p(X)\right) \mid \mathrm{E}=1\right) .
\end{aligned}
$$

There are no clear criteria for selecting the proper function and form of the model to be used for the estimation. As logit and probit models usually produce similar results for bivariate estimation (Caliendo and Kopeinig, 2008), a logit model was thus used to estimate the propensity score in the present study. The selection bias was controlled by including observable covariates that simultaneously influence the decision to join the fatrmer organization and the outcome variables. The covariates include membership, household size, average education of the head of the household, area under sticky rice and agricultural inputs required for sticky rice production e.g., seed, nitrogen fertilizer, pesticides and labor.

Different algorithms are available to idenfity the best control group for the purpose of comparison. The nearest neighbor algorithm is straightforward and reduces bias. In the present analysis, we used the one-to-one nearest neighbor algorithm. Radius matching draws on all the members within the caliper for comparison to avoid the risk of bad matches. Kernel-based matching uses weighted averages of all individuals in the control group to construct the counterfactual outcome where the main advantage is less variance while using more information (Caliendo and Kopeinig, 2008; Dehejia and Wahba, 2002). We used three algorithms to estimate the average impact and also to assess the sensitivity of the final result relative to the matching method.The propensity score matching approach may produce a biased estimation because it only takes observable characteristics into account. Nonobservable characteristics, e.g., farmers' motives, are not included. Other methods like difference in difference analysis (DID) are recommended to account for non-observable characteristics to compare impacts. However, only 51 farmers interviewed in both 2013 and 2015 were the same, thus preventing satisfactory use of DID (we nevertheless conducted a DID on those 51 farmers, and the results are given in the Supplementary Material. The resulting patterns were similar to the ones generated by PSM). This is a limitation of our work. To qualify the effect of group membership, interviews with the local leaders and officials enabled us to select the variables that are the most important for local farmers' livelihoods, where land ranks first, meaning our analysis based on observed characteristics is valid despite being limited.

\section{Results}

Table 2 lists the results of the descriptive analysis of HV sticky rice production in 2013 and 2015. In 2013, the average acreage and yield of the surveyed farmers was respectively, $0.13 \mathrm{ha} /$ household and $3.75 \mathrm{t} / \mathrm{ha}$. Members belonging to a sticky rice organization had a significantly smaller sticky rice acreage $(0.1$ ha/household $)$ than non-members $(0.16$ ha/household). The yield of sticky rice produced by members was significantly lower $(3.52 \mathrm{t} / \mathrm{ha})$ than that produced by nonmembers $(3.96 \mathrm{t} / \mathrm{ha})$.

In 2015 , the overall average sticky rice yield decreased slightly. Members' yields were still lower than non-members', and the difference was significant. Members cultivated a 
Table 2. Household and farming characteristics in 2013 and 2015.

Tableau 2. Caractéristiques des ménages et des exploitations agricoles en 2013 et 2015.

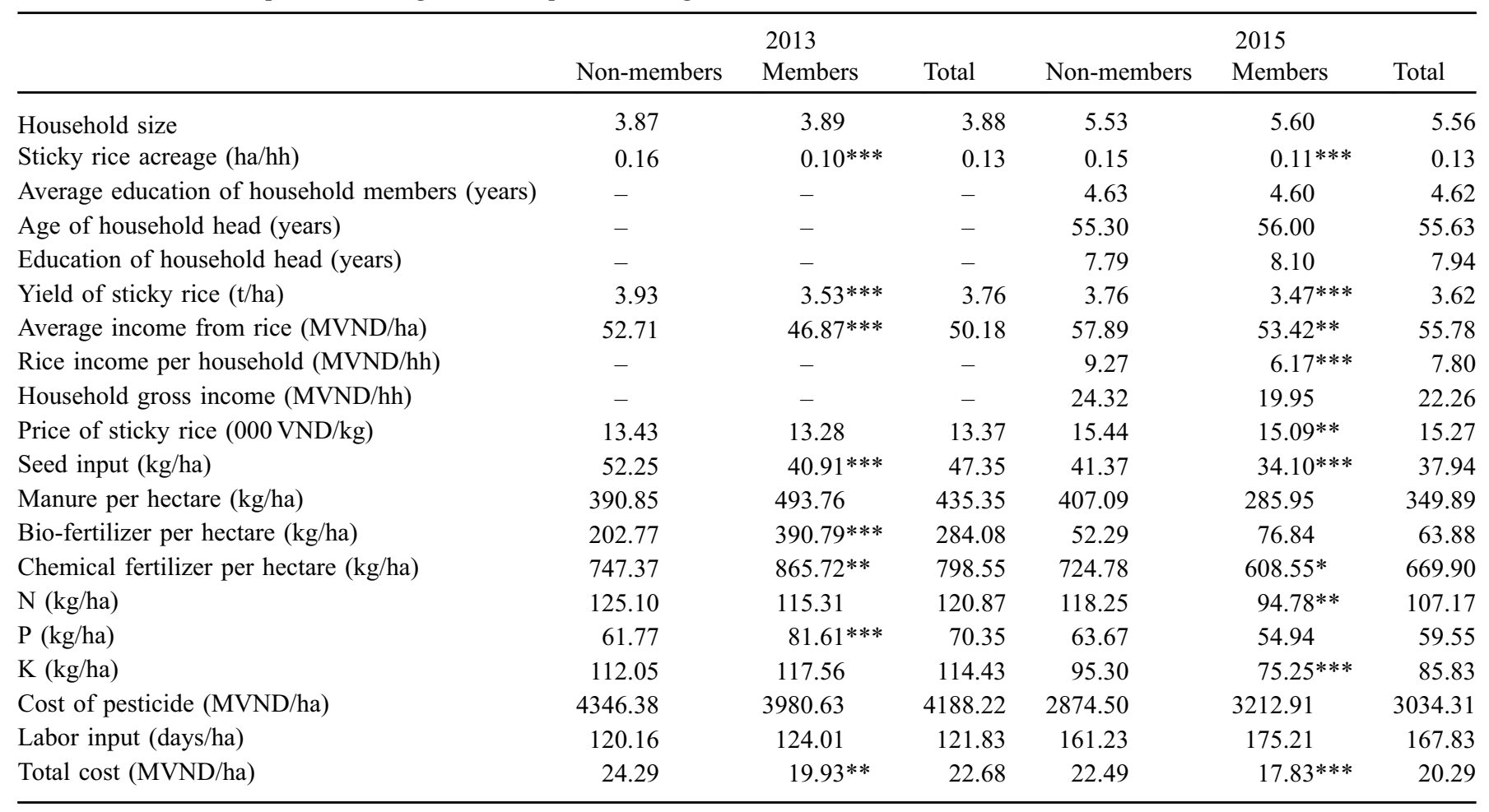

$* * *, * *, *$ refers a significant level of $1 \%, 5 \%$ and $10 \%$, respectively.

significantly smaller acreage of sticky rice, on average 0.11 ha per household, than non-members, who cultivated 0.16 ha per household.

Agricultural inputs include seed, fertilizer (nitrogen, phosphate and kali), pesticides and labor. In 2013, on average, members used less seed than non-members, and the difference was statistically significant. Members used less nitrogen fertilizer, but in this case, there was no significant difference between members and non-members.

In 2015, members still used less seed on average to produce sticky rice. The amount of seed used by members was $35.58 \mathrm{~kg}$ per ha, nearly $10 \%$ less than the amount used by non-members (40.85 $\mathrm{kg}$ per ha). The difference in the amount of $\mathrm{N}$ and $\mathrm{K}$ used by members and non-members was also significant, whereas labor input by members was not significantly higher than that of non-members.

In 2013, there was no significant difference in the income obtained from stikcy rice by members and non-members. Nonmembers tended to sell more of their total rice yield (rather than self-consume), i.e. the share of rice sales was $75 \%$, whereas that of members was $68 \%$. The average price of paddy was 13.37 thousand VND (US\$ 0.671 in 2013-2015) per kg. The price received by members was 13.28 thousand VND/kg (US\$ $0.664 / \mathrm{kg}$ ) which is very close to the average price received by non-members (13.43 thousand VND/kg or US\$ $0.668 / \mathrm{kg}$ ). There was no significant difference in the price of paddy between members and non-members.

In 2015, the household income (including sticky rice) of members was lower than that of non-members. The difference in household income between members and non-members was not significant, even though the gross income from rice obtained by members was significantly lower (6.17 million VND, US\$ 308) per household than that of non-members (9.27 million VND, US\$ 463) per household.

The price of paddy in 2015 differed from that in 2013. The average price of paddy claimed by the members, around 15.09 thousand VND per $\mathrm{kg}$ (US\$ $0.75 / \mathrm{kg}$ ), was significantly lower than that of non-members, 15.44 thousand VND per kg (US\$ $0.77 / \mathrm{kg}$ ).

Table 3 shows that in 2015, the cost of sticky rice produced by members and non-members was similar. The average total cost of sticky rice production for members of the farmer organization was 19.25 million VND (US\$ 9,625) per ha including 9.19million VND (US\$ 459.5) for labor and 10.06 million VND (US\$ 503) for inputs. Similarly, the cost for non-members was slightly higher at 21.43 million VND (US\$ 1071.5) per ha, consisting of 11.33 million VND (US\$ 566.5) for labor and 10.09 million VND (US\$ 504.5) for inputs. Although members paid less for inputs, the difference was not significant.

\subsection{Quantile analysis of the effect of the farmer organization}

The yield of HV sticky rice in 2013 was used as the outcome variable to evaluate the effect of origin certification through a farmer organization (Appendix 2). As mentioned above, the quality of sticky rice grains was affected by flooding in 2013, which in turn, affected the sales price. Although the yield may also have been affected, the effect was less than that 
Table 3. Cost of sticky rice production in 2015.

Tableau. Coût de production du riz gluant en 2015.

\begin{tabular}{llr}
\hline Variable & $n$ & Mean \\
\hline Members & & \\
Total labor cost (MVND/ha) & 82 & 9.19 \\
Cost of inputs (MVND/ha) & 82 & 10.06 \\
Total cost of sticky rice (MVND/ha) & 82 & 19.25 \\
Non-members & & \\
Total labor cost (MVND/ha) & 67 & 11.33 \\
Cost of inputs (MVND/ha) & 67 & 10.09 \\
Total cost of sticky rice (MVND/ha) & 67 & 21.43 \\
Total & & \\
Total labor cost (MVND/ha) & 149 & 10.16 \\
Cost of inputs (MVND/ha) & 149 & 10.07 \\
Total cost of sticky rice (MVND/ha) & 149 & 20.23 \\
\hline
\end{tabular}

on the sales price. In addition, farmers may have used other strategies to adapt to the climate in that year to compensate for the loss. This explains why yield was not significantly affected, which was confirmed comparing the yield in 2013 and 2015. Consequently, yield was selected as outcome in the quantile regression of the input variables. What is more, although the price may have been affected by the time the farmers sold their production on the market, this effect was not linked to the use of inputs.

Farmers surveyed were divided into five groups based on their yield of sticky rice. As the sticky rice yield increases, the negative effect of membership decreases, as the coefficients in the regressions become smaller (Appendix 2). There was no significant effect of membership on the rice yield obtained by the group with the highest rice yield.

In 2015, the effect of origin certification on the levels of income was negative, but the effect was greatest on the group with the highest income (Appendix 3).

\subsection{Propensity score matching of the effect of being a member of the farmer organization}

Appendix 4 compares the estimated treatment effect after implementing propensity score matching to correct the bias. Income from rice in 2013 and household income in 2015 were selected as outcome variables using matching techniques. Matching means that similar treatment and control units are paired in terms of their observable characteristics (Maertens and Swinnen, 2009; Dehejia and Wahba, 2002). The income variables chosen for the two years differed in the econometric analysis but the results were similar and consistent.

In 2013, the income from rice per hectare obtained by nonmembers was significantly higher $(10 \%$ higher before matching) than the income obtained by members. After matching, there was no significant difference in the income obtained from rice by members and non-members. The result of the estimated effect of nearest neighbor matching showed that the income of non-members was 0.21 million VND higher per hectare than that of members, which is less than the figures we obtained using the Radius and Kernel method.
In 2015, the effect of membership on household income was the same, i.e. there was no significant difference in income after matching members and non-members. Initially, nonmembers with an income of 9.34 million VND per household, had a higher income than members with around 6 million VND per household. The household income of non-members was thus more than $50 \%$ higher than that of members. The results of the different estimated effects of the matching methods showed that members had a similar household income to that of non-members.

\section{Discussion}

We now provide some explanations for the lack of an average impact on members' incomes obtained by GI certification through the farmer organization. First, although the aim of the farmer organization is to generate higher prices by improving and communicating on quality, belonging to a farmer organization does not increase sales prices. The heads of the organization told us their members would receive a premium of $500 \mathrm{VND} / \mathrm{kilo}$, i.e., $5 \%$ more, but this was not what was reported by the farmers we interviewed in our surveys. From our interviews with sticky rice traders, we gathered that the reputation of sticky rice is already quite high in the area, and consumers would not be willing to pay a premium for the rice originating from farmer organizations, even though in this case, the origin of the rice is more strictly guaranteed. In a previous study, it was found that a third of consumers would be ready to pay a $20 \%$ price premium for guaranteed shape, shine and fragrance, yet they are not generally aware of the relationship between quality attributes and origin (Diaz et al., 2009). This is all the more true since frauds in which the term "Hoa Vang rice" is used are not sanctioned, and communicating to the public what the "Hoa Vang" indication actually designates is still limited. The bulk of outlets used by the organization are alcohol factories and some retail outlets. Despite many efforts in terms of advertising, the organization has been moderately successful in finding other buyers. Supermarkets prefer to sell sticky rice in bulk than in the organization's packaging. One Hanoi retailer we interviewed said it would be easier to market rice bagged in a $1 \mathrm{~kg}$ package than in the present $2 \mathrm{~kg}$ one. A rural rice wholesaler said that the added value in terms of quality of the organization was not sufficiently clearly demonstrated for traders to be able to offer higher prices than for non-labeled rice. This type of feedback shows that the organization currently lacks an adequate dialogue mechanism with distribution partners.

A second explanation is the decreasing yields that accompany the upgrading of rice quality. Lower yields are indeed frequently observed when the main objective is to improve quality (Neilson et al., 2018). Replacing chemical inputs with organic inputs reduces yield even more because sources of organic inputs are limited. The use of the restored variety also reduces yield. Three farmers we interviewed told us that they had themselves selected varieties that are more resistant to disease than the variety supplied by the organization and that they prefer to use their own choice of seed. Following the principles of sustainable rice intensification, farmers with origin certification use a lower density of seeds to make sure the roots are stronger and take up more 
nutrients, which has a positive effect on rice quality but a negative effect on yield.

The result of the comparison between members and nonmembers led us to the conclusion that GI certification does not produce higher incomes for members than those received by non-members. This can be traced back to what appears to be poor marketing, in line with the results of our literature review. However this result was obtained using synchronic analysis. It thus needs to be completed by a dyacronic analysis that compares the situation of households before and after joining the farmer organization. Indeed, it could be argued that membership allows households with less land to obtain the same yield and income as more favorably endowed households, a positive point for farmer organizations in terms of their impact on equity and rural development. Farmers with more land may also have a certain advantage when it comes to finding customers and negotiating better prices. For less endowned farmers, the involvement of the farmer organization in GI certification plays a crucial role in compensating for their less advantageous position in terms of marketing. This is in line with the findings of Bontemps et al. (2013), who showed that small firms benefit more from geographical indications than large firms.

\section{Conclusion}

This paper investigated the impact of farmer organizations involved in quality and origin certification on farmers' incomes for a commodity traded locally in a region characterized by a high rate of poverty. Literature on this topic is rare and mixed results are reported, not only because it is difficult to enforce the correct use of the label, but also because consumers and traders are unwilling to pay for what may be symbolic quality attributes rather than intrinsic ones if a successful partnership with them is not established by the organization using the GI. Data on household characteristics and economic results were collected from 185 households in 2013 and 149 households in 2015, including members and nonmembers of the farmer organization. Different econometric methods were applied to investigate the effect of the farmer organization involved in GI certifying based on the outcome variables, rice yield, income from rice, and household income.

Our study showed that, considered as a group, farmers who use the GI label obtained a significantly lower income from rice and a significantly lower household income than farmers who do not use the GI label. The analysis based on quintiles showed that as the yield and household income increases, the effect on the yield and income performance of sticky rice of belonging to a farmer organization using a GI decreases. Moreover, members have less land resources, than nonmembers. This suggests a positive effect of GI labeling in terms of the inclusion of farmers with less favorable production and marketing capacities. Sticky rice is a staple food crop with a mature market thanks to its long history and traditional usage. GI certification may thus not attract farmers with more land and established market outlets. However, farmers with fewer observed resources, particularly land, and more difficult access to market have similar outcomes to farmers with more market opportunties. This is an interesting and original result because the economic literature tends to focus on average effects on income and seldom takes the inclusive and equalizing effect of farmer organizations for the less endowned into account. A follow-up study with panel data is recommended to further investigate the impact of farmer organizations on farmers' economic results. It would also be useful to investigate the actual functioning of farmer organizations in terms of decision making and allocation of financial resources, to identify ways for these organizations to reach their objectives more effectively.

The results of our study lead us to make the following policy recommendations. First, for GI certification to have a real impact on sales prices, more regular dialogues between the heads of farmer organizations and their customers, including with rural wholesalers and city retailers, is required to assess traders' requirements in terms of all quality attributes, and to support farmer organizations in communicating the added value for consumers of purchasing the labeled product. Second, the national office of intellectual property, which delivers the collective brand, should be involved in the control and sanctioning of fraudulous use of the label "Hoa Vang" sticky rice. This would increase the specific marketing advantage of the genuine labeled rice. Third, farmer organizations involved in improving quality and marketing have proved they are an effective platform for the inclusion of less endowned farmers and should be supported as such, even though their economic impact is not obvious.

\section{Supplementary Material}

Appendix 1. Results of fixed effect model based on the panel data of 51 farmers.

Appendix 2. Quantile regression on the effect of membership of the farmer organization on sticky rice yield in 2013 .

Appendix 3. Quantile regression on the effect of membership of the farmer organization on household income in 2015.

Appendix 4. Average treatment effect of membership of the farmer organization on income with the PSM method.

The Supplementary Material is available at https://www. cahiersagricultures.fr/10.1051/cagri/2021032/olm.

Acknowledgements. The research was funded by the French National Research Agency (ANR) grant number ANR-11ALID-0006, within the framework of the Illiad project (Local and Innovative Initiatives for Sustainable Food). The overall Illiad project was coordinated by Sandrine Costa (INRAMOISA) from 2012 to 2015 . Support to sticky rice production, processing and marketing in Hai Duong Province has been provided by the Ifad-funded Superchain project between 2007 and 2009 led by Malica research consortium, and by the UKfunded CodI project between 2009 and 2011.

\section{References}

Abebaw D, Fentie Y, Kassa B. 2010. The impact of a food security program on household food consumption in northwestern Ethiopia: a matching estimator approach. Food Policy 35: 286-293. DOI: 10.1016/j.foodpol.2010.01.002

Abebaw D, Haile MG. 2013. The impact of cooperatives on agricultural technology adoption: empirical evidence from 
Ethiopia. Food Policy 38: 82-91. doi:10.1016/j.food pol.2012.10.003.

Akerlov GA. 1970. The market for lemons. Quality uncertainty and the market mechanism. Quarterly Journal of Economics 84: 488500. doi:10.2307/1879431.

Belletti G, Marescotti A. 2011. Origin products, geographical indications and rural development. Labels of origin for food. Wallingford (UK): CABI, pp. 75-91.

Belletti G, Marescotti A, Touzard JM. 2017. Geographical indications, public goods and sustainable development: the roles of actors' strategies and public policies. World Dev 98: 45-57. doi:10.1016/j.worlddev.2015.05.004.

Biénabe E, Marie-Vivien D. 2017. Institutionalizing geographical indications in southern countries: lessons learned from Basmati and Rooibos. World Dev 98: 58-67. doi:10.1016/j.worlddev.2015.04.004.

Bontemps C, Bouamra-Mechemache Z, Simioni S. 2013. Quality labels and firm survival: some first empirical evidence. European Review of Agricultural Economics 40(3): 413-439. doi:10.1093/ erae/jbs034.

Bramley C, Biénabe E, Kirsten J. 2009. The economics of geographical indications: towards a conceptual framework for geographical indication research in developing countries. The Economics of Intellectual Property: 109-149.

Caliendo M, Kopeinig S. 2008. Some practical guidance for the implementation of propensity score matching. J Econ Surv 22: 3172. doi:10.1111/j.1467-6419.2007.00527.x.

Chagwiza C, Muradian R, Ruben R. 2016. Cooperative membership and dairy performance among smallholders in Ethiopia. Food Policy 59: 165-173. doi:10.1016/j.foodpol.2016.01.008.

Cook ML, Chambers M. 2007. Role of agricultural cooperatives in global netchains. In: Working Paper for the Montpellier Workshop organized by INRA-MOISA and Wageningen University. Montpellier (France): INRA-MOISA.

Dehejia RH, Wahba S. 2002. Propensity score-matching methods for nonexperimental causal studies. Rev Econ Stat 84: 151-161. doi:10.1162/003465302317331982.

Deng H, Huang J, Xu Z, Rozelle S. 2010. Policy support and emerging farmer professional cooperatives in rural China. China Economic Review 21(4): 495-507. doi:10.1016/j.chieco.2010.04.009.

Desquilbet M, Monier-Dilhan S. 2015. Are geographical indications a worthy quality label? A framework with endogenous quality choice. European Review of Agricultural Economics 42(1): 129150. doi:10.1093/erae/jbu008.

Diaz V, Wang H, Moustier P, Luan NN. 2009. Consumers' demand for sticky rice in Hanoi. In: Moustier P, Anh DT, Sacklokham S, eds. Linking small-scale farmers to supermarkets and other quality chains, Superchain report, Hanoi: Cirad, Malica, pp. 16-20.

Durand C, Fournier S. 2017. Can geographical indications modernize Indonesian and Vietnamese agriculture? Analyzing the role of national and local governments and producers' strategies. World Development 98: 93-104. doi:10.1016/j.worlddev.2015.11.022.

Fałkowski J, Ciaian P. 2016. Factors supporting the development of producer organizations and their impacts in the light of ongoing changes in food supply chains: a literature review. JRC Technical Report No. EUR 27929 EN. Joint Research Centre, European Commission.

Galtier F, Belletti G. Marescotti A. 2013. Factors constraining building effective and fair geographical indications for coffee:
Insights from a Dominican case study. Development Policy Review 31: 597-615. doi:10.1111/dpr.12027.

Giovannucci D, Josling TE, Kerr W, O’Connor B, Yeung MT. 2009. Guide to geographical indications: linking products and their origins. Geneva: International Trade Centre. https://mpra.ub.unimuenchen.de/27955/.

Hughes J. 2009. Coffee and chocolate: can we help developing country farmers through geographical indications? Report prepared for the International Intellectual Property Institute. Washington DC (USA), 136 p. doi:10.2139/ssrn.1684370.

Ilbery B, Morris C, Buller H, Maye D, Kneafsey M. 2005. Product, process and place: an examination of food marketing and labelling schemes in Europe and North America. European Urban and Regional Studies 12(2): 116-132. doi:10.1177/0969776405048499.

Imbens GW. 2004. Nonparametric estimation of average treatment effects under exogeneity: a review. Rev Econ Stat 86: 4-29. doi:10.1162/003465304323023651.

Jalan J, Ravallion M. 2003. Estimating the benefit incidence of an antipoverty program by propensity-score matching. J Bus Econ Stat 21: 19-30. doi:10.1198/073500102288618720.

Jena PR, Grote U. 2012. Impact evaluation of traditional Basmati rice cultivation in Uttarakhand State of Northern India: what implications does it hold for Geographical Indications? World Development 40(9): 1895-1907. doi:10.1016/j.worlddev.2012.04.004.

Khandker SR, Koolwal GB, Samad HA. 2010. Handbook on impact evaluation: quantitative methods and practices. Washington DC (USA): The World Bank.

Koenker R, Bassett G. 1978. Regression Quantiles. Econometrica 46(1): 33-50.

Ma WL, Abdulai A. 2017. The economic impacts of agricultural cooperatives on smallholder farmers in rural China. Agribusiness 33(4): 537-551. doi:10.1002/agr.21522.

Maertens M, Swinnen JFM. 2009. Trade, standards and poverty: evidence from Senegal. World Dev 37(1): 161-178. doi:10.1016/j. worlddev.2008.04.006.

Michalek J, Ciaian P, Pokrivcak J. 2018. The impact of producer organizations on farm performance: the case study of large farms from Slovakia. Food Policy 75: 80-92. doi:10.1016/j.food pol.2017.12.009.

Moustier P, Tam PTG, Anh DT, Binh VT, Loc NTT. 2010. The role of farmer organizations in supplying supermarkets with quality food in Vietnam. Food Policy 35(1): 69-78. doi:10.1016/j.food pol.2009.08.003.

Neilson J, Wright J, Aklimawati L. 2018. Geographical indications and value capture in the Indonesia coffee sector. Journal of Rural Studies 59: 35-48. doi:10.1016/j.jrurstud.2018.01.003.

Ofori E, Sampson GS, Vipham J. 2019. The effects of agricultural cooperatives on smallholder livelihoods and agricultural performance in Cambodia. Natural Resources Forum 43(4): 218-229. doi:10.1111/1477-8947.12180.

Tregear A, Török Á, Gorton M. 2016. Geographical indications and upgrading of small-scale producers in global agro-food chains: a case study of the Makó Onion Protected Designation of Origin. Environment and Planning A 48(2): 433-451. doi:10.1177/ $0308518 \times 15607467$.

Williams RM. 2007. Do Geographical Indications Promote Sustainable Rural Development? Two UK case studies and implications for New Zealand rural development policy. Lincoln University report. 